Swarthmore College

Works

6-1-2014

\title{
Ensuring Language Acquisition For Deaf Children: What Linguists Can Do
}

T. Humphries

P. Kushalnagar

G. Mathur

Donna Jo Napoli

Swarthmore College,dnapoli1@swarthmore.edu

C. Padden

See next page for additional authors

Follow this and additional works at: https://works.swarthmore.edu/fac-linguistics

Part of the Linguistics Commons

Let us know how access to these works benefits you

\section{Recommended Citation}

T. Humphries, P. Kushalnagar, G. Mathur, Donna Jo Napoli, C. Padden, and C. Rathmann. (2014). "Ensuring Language Acquisition For Deaf Children: What Linguists Can Do". Language. Volume 90, Issue 2. e31-e52. DOI: 10.1353/lan.2014.0036

https://works.swarthmore.edu/fac-linguistics/187

This work is brought to you for free by Swarthmore College Libraries' Works. It has been accepted for inclusion in Linguistics Faculty Works by an authorized administrator of Works. For more information, please contact myworks@swarthmore.edu. 


\section{Authors}

T. Humphries, P. Kushalnagar, G. Mathur, Donna Jo Napoli, C. Padden, and C. Rathmann 


\section{LANGUAGE AND PUBLIC POLICY}

\section{Ensuring language acquisition for deaf children: What linguists can do}

\author{
TOM HUMPHRIES
}

University of California, San Diego

\author{
DONNA Jo NAPOLI \\ Swarthmore College
}

\author{
POORNA KuSHALNAGAR \\ Rochester Institute \\ of Technology \\ CAROL PADDEN \\ University of California, \\ San Diego \\ Gaurav Mathur \\ Gallaudet University \\ CHRISTIAN RATHMANN \\ University of Hamburg
}

Parents of small deaf children need guidance on constructing home and school environments that affect normal language acquisition. They often turn to physicians and spiritual leaders and, increasingly, the internet. These sources can be underinformed about crucial issues, such as matters of brain plasticity connected to the risk of linguistic deprivation, and delay or disruption in the development of cognitive skills interwoven with linguistic ability. We have formed a team of specialists in education, linguistics, pediatric medicine, and psychology, and at times specialists in theology and in law have joined our group. We argue that deaf children should be taught a sign language in the early years. This does not preclude oral-aural training and assistive technology. With a strong first language (a sign language), the child can become bilingual (with the written form of the ambient spoken language and, perhaps, the spoken form), accruing the benefits of bilingualism. We have published in medical journals, addressing primary care physicians, in a journal with a spiritual-leader readership, and in a health-law journal. Articles in progress address medical educators and practitioners. Team members present findings at conferences, work on lobbying and legislative efforts with the National Association of the Deaf, and spread the word at conferences of target audiences. We share our work in Word format, so that anyone can easily appropriate it for our common interests. One of our articles has been downloaded over 27,000 times (as of April 2014), and we are asked to consult with committees in other countries as they draft national policies.

Keywords: deaf children's rights, first language acquisition, brain plasticity, sign languages, ethics and activism in scholarship

1. The policy PRoblem. We argue that beliefs about spoken and sign languages among underinformed professionals have serious consequences; parents are advised to make decisions and construct home and school environments that affect normal language acquisition among deaf children. In the United States, around 96\% of deaf children are born to hearing parents (Moores 2001) who have no family history of using a sign language. The remaining $4 \%$ are born to deaf parents, and in most cases, though not always, the primary language of the home is a sign language. Many hearing parents are initially uninformed about fundamental language matters and turn to the medical profession, the internet, their spiritual leaders, and/or their friends and family for advice about the language choices they need to make for their children (Luterman 1979, Gregory 1995, Porter \& Edirippulige 2007). Too often, those they turn to are under- or misinformed about the language needs of deaf children (Meader \& Zazove 2005). Parents are often told that the best way for their child to acquire spoken language is to raise them without sign language. In many cases, parents are advised that sign is to be chosen only as a last resort (Petitto 1998, Johnston 2006), and that great effort should be devoted instead to the acquisition of speech. Given that these parents are hearing and unfamiliar with deaf people's lives and sign languages, many opt for the more typical oral and/or aural choice (speech and audition only). 
In addition, over $80 \%$ of deaf children in developed countries receive cochlear implants (CIs), and the percentage is increasing (Boyes Braem \& Rathmann 2010). CI is now the treatment of choice in the medical sciences for most children with sensorineural hearing loss (SNHL) (Niparko 2009), and sign language is seen as both a barrier to learning speech and a symptom of treatment failure (Broesterhuizen \& Leuven 2008). The most frequent recommendation is to isolate deaf children from sign language environments during the important years of first language acquisition (Wrigley 1997, Padden \& Humphries 2005, The Canadian Hearing Society 2005, Krausneker 2008).

However, CI has a variable rate of success with respect to long-term language development. (Rather than interrupt the discussion with a long list here, we indicate these references with two asterisks in the bibliography.) The factors involved in CI success are not well understood, although age of the patient (Tomblin et al. 2005, Vermeire et al. 2005, Nicholas \& Geers 2007, and many others), onset of deafness (Leung et al. 2005, Green et al. 2007), coding strategies (Skinner et al. 2002), family socioeconomiceducation level (Svirsky et al. 2004, Szagun 2008), and surgical technique (Meshik et al. 2010) are relevant. Even under optimal conditions, CI implantation does not guarantee first language acquisition. Many implanted children who are born deaf or become deaf in the first few years of life experience little to no success in language acquisition with a CI, and only turn to sign language after the early critical period. Unfortunately, this means these children run the risk of never having completely fluent use of either a spoken or a sign language.

Further, not meeting the language needs of deaf children can mean harm to their psycho-social health, putting them at risk for depression, behavioral problems, social disorders, and juvenile delinquency (Northern \& Downs 2002, Andrews et al. 2003, Schick et al. 2006, Leigh 2009). They are more likely to engage in criminal behavior in later life (Kleimenov \& Shamkov 2005, Miller et al. 2005), to be the target of abuse of various sorts (Sullivan \& Knutson 2000, Knutson et al. 2004, Kvam 2004), and to rely on the social services safety net. Long term, language access is critical for the participation of deaf people in preventive health and health care services (Iezzoni et al. 2004, McKee, Barnett, et al. 2011, McKee, Schlehofer, et al. 2011), education (Oliva 2004), mental health care (Steinberg et al. 1998), the workplace (Rashid et al. 2011, Haynes \& Linden 2012), and social relationships (Gerich \& Fellinger 2012).

Additionally, failure to acquire language in the early years results in delay or disruption in the development of cognitive skills that interweave with linguistic ability. Such children have trouble with verbal memory organization (Rönnberg 2003), mastery of numeracy and literacy (MacSweeney 1998), and higher-order cognitive processing such as executive function and THEORY OF MIND (Courtin 2000, 2010, Courtin \& Melot 2005, Morgan \& Kegl 2006, Schick et al. 2007, Courtin et al. 2008, Figueras et al. 2008, Marschark \& Hauser 2008, Remmel \& Peters 2009).

Globally, SNHL is one of the most common among those birth conditions labeled 'defects' by the medical profession. Profound SNHL occurs in two or three out of 1,000 newborns in North America (National Institutes of Health 2011) and is as high as three out of 1,000, depending on the severity threshold used in a given study and whether unilateral hearing loss is included (Spivak 2007, Kozak et al. 2009). In Germany, profound SNHL occurs in one to three out of 1,000 newborns (Schnell-Inderst et al. 2006). In Nigeria, a striking number of twenty-eight per 1,000 infants have permanent congenital and early-onset hearing loss (Olusanya et al. 2008). Poverty, combined with many other factors, produces higher levels of SNHL; lower socioeconomic areas around the world are home to higher numbers of people with SNHL (for Canada, see Bowd 2005; for 
India, see Reddy et al. 2006; for Malawi, see van Hasselt \& van Kregten 2002; for Pakistan, see Musani et al. 2011; for the United States, see many, especially Oghalai et al. 2002 and Prince et al. 2003). Most deaf and hard-of-hearing children live in developing countries (Jauhiainen 2001, Tucci et al. 2010). Nevertheless, in developing countries, an increasing percentage of deaf children do get CIs, and there is an outcry among the medical profession for CI funding (Garg et al. 2011, Saunders \& Barrs 2011). Postnatal causes of SNHL include bacterial meningitis, beta-hemolytic streptococcal sepsis, toxins, trauma, and late onset due to gene mutation (Paqarkar et al. 2006); by school age, six to seven out of 1,000 children have permanent hearing loss, most of which is SNHL (Bamford et al. 2007).

Given all of these frequency data and the trend toward speech-only training in medical settings, it is clear that a significant number of children in the world with SNHL are likely to be given CIs and kept away from sign language during their early years, and, consequently, run a high risk of linguistic deprivation and related cognitive deficits.

2. The Linguistic EVIDENCE That INFORMS THIS POLICY PROBlem. Before entering into the linguistic evidence, it is important to recognize nonlinguistic debates concerning language choices for deaf children. The Food and Drug Administration (FDA) approved the use of CIs in adults in 1984, in children aged two and above in 1990, and in children aged twelve months and above in 2000. Almost this entire time, there has been a controversy revolving around the question of whether CIs would remove a child from Deaf communities and eventually threaten Deaf communities with extinction (Winefield 1987, Grant 2008). There has also been much discussion over ethical concerns of CIs that go beyond linguistic issues and surgical-risk issues (Christiansen \& Leigh 2002). Here, we set these debates aside not because they are wrong-minded, but because they obfuscate the linguistic issues, which, by themselves, are straightforward and compelling.

With respect to the linguistic evidence, two points can be made, one involving recognition of the fact that both the oral-aural and the manual-visual modalities of language nourish the brain's language mechanism, and the other involving the recognition of changing plasticity in the brain with respect to first language acquisition.

2.1. Two modalities of LANguage. First, language and the brain are flexible with respect to modality. Both spoken and sign languages can nurture brain development, as is shown by much research on the structure of particular spoken and sign languages and on language universals (see a multitude of articles in many linguistics journals, including Sign Language \& Linguistics and Sign Language Studies, as well as more recently in journals that do not focus on sign languages, such as Language; and see a variety of comprehensive books, such as Sandler \& Lillo-Martin 2006, Brentari 2010, Pfau et al. 2012), on language acquisition (Newport \& Meier 1985, Meier \& Newport 1990, Petitto \& Marentette 1991, Lillo-Martin 1999, among many others), on language processing (Emmorey 2001, among many others), on neurolinguistics (Poizner et al. 1987, Neville 1995, among many others), on language pathologies (Corina 1998, among many others), and on second language learning (Newport 1990). (We have chosen to cite seminal works, which laid the foundation for much following research.)

Too often in the relevant medical literature, we find the confused belief that language is equivalent to speech despite a half-century of research on sign languages. For example, consider this statement from Kral and O'Donoghue (2011:485): 'Nonetheless, the available evidence suggests that early intervention through sensory restoration offers the best hope of mitigating the pernicious effects of hearing deprivation on multiple lev- 
els of brain function'. The authors recognize that absence of hearing can lead to absence of language, which can, in turn, lead to cognitive deficits, but they see 'sensory restoration' (i.e. auditory restoration) as the only way to ensure language and to prevent cognitive deficits that follow from absence of language input. This quotation is representative of the basic misconception that equates language with speech. Published policy statements about deaf children recommend early screening; early intervention; close and continued monitoring of the child's communicative, language, motor, cognitive, and social-emotional development; and protection of infant and family rights through informed choice, decision making, and consent (Early Hearing Detection and Intervention Information \& Resource Center 2004, Joint Committee on Infant Hearing 2007, Department of Health and Human Services 2009, and so on). Frequently, such recommendations discuss almost exclusively audio-verbal therapy (AVT) via habituation and vocal output, although more recent policy statements emphasize cognitive language development and the importance of nurturing and communicating with the child regardless of modality. Nevertheless, primary care physicians express a lack of confidence in discussing follow-up procedures and intervention needs for deaf newborns because of their lack of familiarity with deafness (Moeller et al. 2006), and thus immediately refer the parents to audiologists, whose primary concern is auditory input, often with no or only skeptical recommendations of looking into sign language options. Evidence that there are at least two modalities that offer a normal pathway to language acquisition is often disregarded, leading to a failure to understand and take advantage of the flexibility of the human brain.

2.2. First language aCQUisition and PLASTICITy. The second relevant linguistic point with respect to the policy problem is that first language acquisition takes place most naturally and successfully in the first few years of life; if a child is not exposed to accessible or learnable language on a regular and frequent basis before the age of around five years old, that child is unlikely to ever use any language with native-like fluency across the grammar (Lenneberg 1964, 1967, Mayberry 1994, 1998, Hall \& Johnston 2009, Hudson \& Newport 2009). Over the years we see a gradual decline in the ability to acquire a first language (note that a second language is a separate matter with distinct considerations - our concern here is first language acquisition). Some areas of the grammar seem to be resilient; that is, even in the absence of early input, they can be mastered later in life (see Goldin-Meadow 2003, 2005), such as word order, while other areas of language are more fragile and, without input in the very early years, tend to never get mastered, such as complex morphology, as in verb agreement (Wood 2007, 2011). Evidence for this sensitive (or critical) period comes from children whose language development is somehow special, and from children who have been neglected and/or abused.

APHASIC, BILINGUAL, AND DEAF INDIVIDUALS. Lenneberg (1967) reported that children with acquired aphasia can recover completely, but adults cannot, concluding that there must be a critical period for language acquisition. Later research on aphasia shows variable recovery from aphasia with children (Woods \& Carey 1979, for example), but worse prognosis for adults (Martins 2004). Other works on aphasia likewise support a critical period for first language acquisition (Alajouanine \& Lhermitte 1965, and Goorhuis-Brouwer 1976, a study written in Dutch and reported on in English in Snow \& Hoefnagel-Höhle 1978).

Similarly, evidence on bilingualism supports the existence of a sensitive period. In a study of twenty-year-olds comparing monolinguals, early bilinguals (before the age of 
ten), and late bilinguals, early bilinguals and monolinguals displayed the same level of proficiency in English and a greater proficiency than that of late bilinguals. Further, the age of onset of bilingualism was negatively correlated to English proficiency across all bilinguals (Luk et al. 2011).

Finally, and most important to us, studies of deaf children who did not receive accessible language until after the critical period due to lack of hearing aids (Curtiss 1994, Grimshaw et al. 1998) or because they were denied sign language (Mayberry \& Fischer 1989, Emmorey \& Corina 1990, Newport 1990, Emmorey 1991, Mayberry \& Eichen 1991, Wood 2007, 2011, among many others) show reduced language facility. Deaf children who were first exposed to an accessible language (i.e. a sign language) at varying ages show varying degrees of mastery of language as they age, with early learners doing far better than late learners overall (Newport \& Supalla 1987, Johnson \& Newport 1989, Newport 1990, 1991, Boyes Braem 1999, Galvan 1999, Helmuth 2001, Newport et al. 2001, Singleton \& Newport 2004, Morford \& Hänel-Faulhaber 2011, Wood 2011, Cormier et al. 2012, Skotara et al. 2012).

NEGLECTED AND/OR ABUSED INDIVIDUALS. Other evidence for the first critical period comes from unfortunate incidents of neglect and abuse so severe that children did not acquire any language by the end of the first critical period, and thus were linguistically deprived and accordingly severely limited in their interactions with other humans and in their cognitive functions. These include cases of children discovered growing up 'wild' without being surrounded by human language (Shattuck 1980) and cases of children criminally abused (Curtiss 1977). A large-scale incidence of this is the case of children left in profoundly understaffed orphanages in Romania, where in 1999 it is estimated that there were at least 60,000 children languishing in state-run orphanages (Cohn 2011). In 2000, the Bucharest Early Intervention Project placed some of the children with foster families (Zeanah et al. 2003). They then studied the development of three groups: children remaining in orphanages, children in foster homes, and a control group of children with their original parents. Their research shows that early institutional neglect led to cognitive and socio-emotional deficits and psychiatric disorders. While foster intervention enhanced development, some areas of neural activity, cognition, and social-emotional functioning were resistant to recovery unless intervention took place before the age of two years. Language development fell among those functions. Studies of similar orphanages in China and Russia confirm these findings (Nelson et al. 2007).

Further, a recent study of the Bucharest Early Intervention Project (Drury et al. 2012) shows that the telomeres (the protective caps on the ends of chromosomes) of children in the Romanian orphanages grew shorter the longer they remained there. In other words, neglect has a biological effect; in particular, it changes the architecture of the brain. This is pertinent evidence that without proper cognitive nourishment, cortical activities are curtailed. In particular, the language mechanism no longer functions properly for fluid receptive and expressive language behavior.

2.3. Relevance to THE POLICY PROBlem. The combination of these two facts, that cognitive ability can develop in either language modality and that there is a sensitive period for first language acquisition (regardless of whether abuse or neglect is involved), is of crucial relevance to the problem. While the first fact is by and large ignored in the literature that favors CI, the second fact has long been accepted. Much research has shown better auditory results with earlier implantation; this has been the spur to implanting children before the age of two, and often before the age of one 
(Yoshinaga-Itano et al. 1998, Yoshinaga-Itano et al. 2000, Waltzman \& Roland 2005, among many others). The crucial problem is that even with early implantation, the level of aided hearing is less than optimal, which makes acquisition of a spoken language imperfect and difficult and, most of all, unpredictable (Santarelli et al. 2008). The problem is magnified if the child's environment is noisy and unclear. The bottom line is that many children do not acquire a spoken language fully with a CI, and one cannot predict with reliability which children fall into that group. Even work that is explicitly supportive of CI includes statements such as 'there remains huge, unexplained, variation in outcomes from implantation and the challenges of ensuring life-long use and benefit remain' (Archbold \& O’Donoghue 2009:457). For this reason, the failure of the relevant medical professionals to recognize the viability of sign languages means that these children run a risk of, and indeed often experience, linguistic deprivation. But sign languages are viable human languages, with all of the cognitive benefits attributed to spoken languages. Further, sign languages are accessible to all deaf children, even to the deaf-blind child, since there are tactile versions of sign languages (Mesch 2001). If deaf children acquire a sign language during the early years of life, they will not risk linguistic deprivation and the consequent cognitive deficits.

Many studies show that deaf children who sign achieve better in school than those who do not, regardless of other factors (such as whether their parents are deaf or hearing and whether they have assistive hearing devices and/or oral training) (Padden \& Ramsey 2000, Strong \& Prinz 2000, Mayer \& Akamatsu 2003, Paul 2003, Schick 2003, Allen et al. 2007, Wilbur 2008). Indeed, ASL skill above other possible factors correlates strongly with reading achievement (Chamberlain \& Mayberry 2008).

Moreover, the deaf child who acquires a sign language and then learns the written and, perhaps, spoken form of a spoken language is bilingual. Bilingualism has great benefits for the deaf child in cognitive, social, and educational areas (Wilbur 2001, Christiansen $\&$ Leigh 2002). In fact, both the sign language and the spoken language of bilingual deaf children display more syntactic complexity than that of their monolingual peers (KlatterFolmer et al. 2006). In addition, the evidence that high proficiency in two or more languages results in more creative thinking in problem solving, and better mental flexibility and cognitive control that persists through late adulthood, is firm (Cummins \& Gulustan 1974, Prinz \& Strong 1998, Bialystok et al. 2004, Baker 2006, Lightbown \& Spada 2006, Bialystok et al. 2007, Kushalnagar, Hannay, \& Hernandez 2010). All around the world children are raised multilingually, and the bilingual-bicultural trend for deaf education is a mega-trend (Munoz-Baell et al. 2008). Dual proficiency in a sign language, such as American Sign Language, and in a spoken language, such as English, affords the deaf child the benefit of adapting to both signing and nonsigning peer groups with greater ease, resulting in better overall socio-emotional and behavioral development (Marschark 2009). Information of this sort will, we hope, disarm those who are strongly attached to the promotion of CI-only choice.

3. ReCOMMENDATIONS THAT FOLLOW FROM THE EVIDENCE. One basic recommendation follows from the evidence.

Overall Recommendation: All deaf newborns and newly deafened small children should learn a sign language, regardless of whether they receive a CI or a hearing aid.

Several more specific recommendations follow from this basic one.

(1) Medical education must be updated and include linguistic considerations. Medical professionals should be trained in recent research about language acquisition, par- 
ticularly with respect to the issues of linguistic deprivation for those children at risk, primarily deaf children. Medical schools, nursing schools, and schools of public health should include this information in their curriculum.

(2) Delivery of medical care to deaf children should be coordinated across the relevant health professionals, including audiologists, psychologists, surgeons, and rehabilitation teams. These teams should stay in constant contact with and respond to input from parents, sign language teachers, and classroom teachers. This way, the risk of linguistic deprivation can be caught early and responded to appropriately.

(3) Advice from medical professionals must be accurate and adequate. Parents of deaf newborns and newly deafened small children should be advised to teach their child sign language, regardless of whether the child also uses hearing aids or a CI. This means the entire family should learn sign language; and since the biological health of the language mechanism is at stake, this is properly a medical matter, so it is the medical profession's responsibility to tell the parents this.

When the entire family uses sign language at the dinner table, for example, the deaf child has visual access and picks up on incidental information on a variety of topics. Developmentally, the inclusion of the child in family dialogues promotes healthy psychosocial and emotional functioning (Hauser et al. 2010). The deaf child is likely to feel included in family conversations and is less frustrated, as is commonly reported in other situations with communication barriers. This has been self-reported as having an important impact on the deaf youth's quality of life, and the perception of being included in family dialogues is associated with fewer reports of depression symptomatology (Kushalnagar et al. 2011). Deaf children whose hearing parents and siblings, particularly hearing mothers, sign with them demonstrate language expressiveness and theory of mind on a par with hearing children of the same age (Spencer 1993, Schick et al. 2007).

(4) More research needs to be done on second language learning, especially in a second modality. Second language learning is difficult for adults (Krashen 1981 and later work by many), perhaps even more so when the new language is in a different modality. Hearing relatives of a deaf child are going to need help in learning a sign language. Projects such as VL2 at Gallaudet University, ${ }^{1}$ for example, should be adequately funded.

(5) Deaf children should be brought into contact with deaf signing children and adults frequently. The family of a deaf child should not feel the burden of being good sign language models for the child. The important point is that family members engage in frequent, direct language interaction with the deaf child, but the family must understand that their own efforts will not be enough. Parents of deaf children should help them find other deaf children to socialize with in a common language- - community of others like themselves-without continual adult intervention in that communication. Individual interpreters, who act as surrogate teachers or even parents in the classroom, often have little contact with the deaf community. As a result, deaf students can be limited to dyadic groups for communication, which do not approach the richness and complexity of language as used by a larger community. It appears the optimal way to ensure the needed exposure is to participate in group discourse.

Given this, medical advisors must inform the family that the deaf child needs to be brought into contact with a community of deaf signers so as to be exposed to consistent and multiple models of signing on a regular and frequent basis. Families need to be-

${ }^{1}$ http://vl2.gallaudet.edu/ 
come informed about the local culture of Deaf people and help their child (and the whole family) to participate in Deaf events. There are good publications out there to help, like Lane et al. 1996, Padden \& Humphries 2005, Bauman 2008, Bauman \& Murray 2009, Marschark 2009, and Marschark \& Spencer 2010, 2011, all of which provide substantial references.

(6) Advice from others outside the hearing sciences and medical profession must be better informed about pertinent language matters. These advisors include spiritual leaders, particularly since the risk of depression or other psychosocial stress on the part of deaf children and their parents may bring them to these leaders for guidance (Spahn et al. 2003, Turner et al. 2007, Mellon 2009, Kushalnagar et al. 2011). So schools of theology should include information on first language acquisition particularly as it pertains to deaf children in their curriculum. Others in counseling professions need to be similarly informed.

(7) Make sign language accessible to hearing parents and their deaf child. If a family of a deaf child does not have easy access to a signing community, they must take a very strong active role in providing their child with a sign language. First, the family must try to learn a sign language in the best way possible, which may require driving a substantial distance to classes. If the local community is small, the family can enlist the whole community in the effort to learn a sign language and to communicate with the deaf child in that sign language. A community might want to advertise for and hire a sign language teacher to come and stay in their community for an extended period of time, teaching everyone who is willing to learn. There are also multiple online sites and DVDs to help someone learn a sign language (see the websites of Dawn Sign Press in the United States, Forest Books in the United Kingdom, or Karin Kestner Verlag in Germany, for example ${ }^{2}$ ).

Second, the family should find out about camps for deaf children, where sign language is used and deaf children learn about and get welcomed into Deaf culture. Many such camps exist: in the United States they are scattered across the states; in Germany the German Deaf Youth Association and German Deaf Association of Hard-of-Hearing annually organize camps for Deaf and hard-of-hearing children and youth. Some have scholarships available. Some are for the entire family. There are various websites with up-to-date information on such camps (in the US: Summer Camps for Deaf and Hard of Hearing Children and Teens; ${ }^{3}$ in Germany: Bundeselternverband gehörloser Kinder e.V. ${ }^{4}$ ).

Third, the family must be resourceful. Since it is important that others sign with the deaf child, the family could start a sign language class with parents and children who are not deaf. If the family has relatives in a city with a thriving Deaf community, visiting or even arranging to spend time there may be a significant act that makes a world of difference to the child's development. The family might want to get online (using current video technology: Skype, FaceTime, gChat, ooVoo, Facebook, etc.) with someone who knows many people in the Deaf community to see if a Deaf family might like to come visit them for extended periods. The deaf child in one's home makes the home eligible to obtain a videophone setup from a video relay service. Alternatively, one can install videophone software in a home computer. With this setup, the family and the deaf child can talk in sign language directly via video to deaf people whom they meet and

\footnotetext{
${ }^{2}$ http://www.dawnsign.com/, http://www.forestbooks.com/, http://www.kestner.de/

${ }^{3} \mathrm{http} / / /$ www.gallaudet.edu/clerc_center/information_and_resources/info_to_go/resources/summer_camps .html

${ }^{4}$ http://www.gehoerlosekinder.de/
} 
form stronger relationships. Sign language tutoring via videophone might even be arranged. These setups often cost nothing to the family except an internet connection. If the family has opportunities to live in an urban area that has a Deaf community, now might be the time to realize those opportunities.

These family responsibilities can be costly in a number of ways beyond money and time. Knoors and Marschark (2012) argue that using sign language can hinder family dynamics and that learning a sign language can be beyond the abilities of some family members, particularly older ones. We would suggest that, regardless of whether family members learn a sign language, a deaf child born into a hearing family always impacts family dynamics simply by virtue of the fact that the child is deaf. Further, every deaf child is entitled to be recognized and accepted as deaf and to develop their own identity as a deaf person. The United Nations Convention on the Rights of Persons with Disabilities (2006) calls upon states to protect the rights of deaf children by 'facilitating the learning of sign language and the promotion of the linguistic identity of the deaf community' and by ensuring that their education 'is delivered in the most appropriate languages and modes and means of communication for the individual, and in environments which maximize academic and social development'.

Knoors and Marschark (2012) point out further that bilingual education for deaf children has not had uniform success. However, the questions of how to ensure access to language in the early years of life and how to educate deaf children are distinct. Many and complex educational issues arise regardless of which kind of program a child enters (whether one of the various kinds of mainstreaming programs or one of the various kinds of bilingual/bicultural programs; see Ramsey 1997, Stinson \& Liu 1999, Oliva 2004, Marschark 2009, and many others). We are confident that present and future efforts (including more research) will lead to better-qualified teachers using more appropriate and efficacious methods and materials (see Humphries 2013). The fact remains, however, that the cognitive factor that correlates best to literacy among deaf children is a foundation in a first language. Much earlier work shows this, and the most recent findings continue to confirm it: Davidson and colleagues (2014) show that children with CIs who also sign perform better in standardized language testing than children with CIs who do not have exposure to a sign language. (Again, we choose not to interrupt the flow of the argument with a long list of earlier works, so instead mark the relevant references with three asterisks in the bibliography.)

(8) Government sources must fund sign language instruction for these families. Every human has a right to language (as we argue in Humphries et al. 2013). Therefore, instruction in a sign language should be funded by federal and state governments for all deaf children and their families. This funding should continue at least until the age of twelve.

(9) The current risks associated with CIs need to be reduced. The risks of harm associated with CIs should be more widely understood, and the current high risk of linguistic consequences due to using CIs only as a response to deafness in the family needs to be alleviated greatly by the use of sign language along with CIs. Cochlear implants run a host of risks beyond linguistic deprivation. All surgeries come with risks, and surgeries involving the brain may be particularly troubling. With CI surgery, many complications arise, including injury to the facial nerve, necrosis and breakdown of the flap, injury to hair follicles, improper electrode placement, postsurgery infection under the flap and in the middle ear, and meningitis (Cohen \& Roland 2006, McJunkin \& Jeyakumar 2010, Rubin \& Papsin 2010, Thom et al. 2013). There is also a huge risk (40\% to $74 \%$ of patients) of vertigo that can last for years (Steenerson et al. 2001, Walker 2008). 
The apparatus can fail, requiring repeated surgery with all of the same associated risks (Borkowski et al. 2002, Marlowe et al. 2010). Since many CI surgeries disable the cochlea (O'Reilly et al. 2008), the implanted ear loses whatever residual hearing it had; so if the CI does not offer language access to the child, then the surgery has, in fact, had a result contrary to its very intention. The harms of cochlear implant surgery are increasing as the popularity of binaural implantation goes up (Snow \& Wackym 2009), while the claimed benefits have yet to be established (and see the results in Tyler et al. 2010). Further, some deaf and hard-of-hearing children are implanted even when they already recognize up to $30 \%$ of sentence material with or without a hearing aid (Tobin 1995), which is a better recognition rate than many children have post implantation. These children actually might be losing ground with respect to speech skills. And, finally, hearing aids do not present the surgical risks of CIs and may well offer comparable or better advantages with respect to speech development, depending on the particular needs of individual children (Figueras et al. 2008). We therefore believe that no child should be implanted unless implantation is accompanied by sign language, and there is a very strong chance that the child will have excellent oral communication skills as a result of the child's curiosity and motivation for speaking, the child's bias toward auditory learning style, and the child's neural response to implantation.

4. What we have been Doing. We are a team with a core of a developmental psychologist, a pediatrician, an education scholar, and a group of linguists. At various times our team has been augmented by additional pediatricians, a philosopher, a theologist, and a lawyer. Most, but not all, of the core have been active in all our projects.

We write articles aimed at ensuring the right of deaf children to have a language, and thus to participate in human society (Kushalnagar, Mathur, et al. 2010, Blankmeyer Burke et al. 2011, Humphries et al. 2012a,b, 2013). Some of us have presented our work at national and international conferences. Most of our articles have been aimed at medical professionals (see e.g. Humphries et al. 2014), particular the primary care physician, although one was aimed at spiritual leaders, and a recent one (Humphries et al. 2013) is aimed at lawyers and legislators. We hope to get our information into the curriculum for health sciences courses in general, and into the core curriculum for medical schools and nursing schools, and one of our papers in progress is aimed at trying to bring that about. The fact that our team has specialists in a number of different areas allows us to complement each other's knowledge of both substance and the terminology/culture of different fields. An article aimed at physicians, for example, has a different style from one aimed at bioethicists, or one aimed at ministers, and so on.

While our arguments and recommendations may be obvious to the linguist reader, they come as a surprise (sometimes a disturbing one) to many outside our field. Since our first publication came out in 2010, we have been contacted by various groups and individuals around the globe in their endeavors to protect deaf children. In 2012, we exchanged emails with a committee in Denmark as they reworked their national policy toward the language and education needs of deaf children; we advised them on substance as well as wording of the policy. In 2013, we exchanged emails with members of the National Association of the Deaf (NAD) in the United States while they were working on lobbying and legislative efforts. One of our team was asked to join the NAD Education Policy Committee and is helping to prepare a position paper and other information pieces (on the effects of language deprivation and accurate information on the risks of CIs) for this organization. One of our 2012 articles (Humphries et al. 2012a) has been downloaded over 27,000 times (as of April 2014), so we are steadily attracting attention to the problem. 
We also reach out to others by attending meetings at which we have a chance of influencing interested individuals who might be able to advance our cause. For example, at the annual Health Law Professors Conference hosted by the American Society of Law, Medicine, \& Ethics in June, 2013, we gathered contact information from professors who teach in health law and bioethics and then sent them copies of our articles with a suggestion of how they might use them in their classes. When we spread the word among colleagues in Deaf Studies, particularly from other countries, we give them Microsoft Word versions of our articles, rather than PDF versions, so that they can easily copy and paste the material and use it in whatever way best suits them to advance our shared goals.

Beyond the articles, we have published a decision-making tool for patients and their physicians to share, called an OPTION GRID. These grids give a summary table that allows comparisons between options a patient (or a patient's family) faces by listing frequently asked questions with very short answers supported by an evidence document that gives references for further readings. Typically a patient reads the grid then meets with the physician to discuss it and make a final decision. Option grids have been shown to be effective in enhancing patients' confidence as they make decisions even about very complex matters and to increase their involvement in their own treatment (Elwyn et al. 2013). Our option grid is labeled Language Options for Deaf Newborns. It is available through the website http://www.optiongrid.org/, which is administered at Dartmouth College by a collective of health professionals. We are open to suggestions from readers and we are open to sharing our materials and our wisdom based on our experiences thus far about what works and what does not, in setting up an activist team, in working as a team, and in choosing sites for publication. We still have much to learn and a lot of work ahead, but we are encouraged by the results to date and we have not slowed down; if anything, our pace has picked up.

\section{REFERENCES}

Alajouanine, Théophile, and François Lhermitte. 1965. Acquired aphasia in children. Brain 88.653-62.

Allen, Shannon; Doreen Deluca; and Donna Jo Napoli. 2007. Societal responsibility and linguistic rights: The case of deaf children. Journal of Research in Education 17.41-53.

Andrews, Jean F.; Irene W. Leigh; and Mary T. Weiner. 2003. Deaf people: Evolving perspectives from psychology, education, and sociology. Boston: Allyn \& Bacon.

Archbold, Sue, and Gerard M. O'Donoghue. 2009. Cochlear implantation in children: Current status. Paediatrics and Child Health 19.457-63.

BAKER, Colin. 2006. Foundations of bilingual education and bilingualism. 4th edn. Clevedon: Multilingual Matters.

Bamford, John; Heather M. Fortnum; K. Bristow; J. Smith; G. Vamvakas; Linda Davies; Rod S. Taylor; P. Watkin; Sarita Fonseca; Adrian Davis; and Sally E. HiND. 2007. Current practice, accuracy, effectiveness, and cost-effectiveness of the school-entry hearing screen. Health Technology Assessment 11.1-168.

Bauman, H-Dirksen L. (ed.) 2008. Open your eyes: Deaf studies talking. Minneapolis: University of Minnesota Press.

Bauman, H-Dirksen L., and Joseph J. Murray. 2009. Reframing: From hearing loss to Deaf gain. Deaf Studies Digital Journal 1. Online: http://dsdj.gallaudet.edu/index .php?issue $=1 \&$ section_id $=2$ \&entry_id $=19$.

Bialystok, Ellen; Fergus I. M. Craik; and Morris Freedman. 2007. Bilingualism as a protection against the onset of symptoms of dementia. Neuropsychologia 45.459-64.

Bialystok, Ellen; Fergus I. M. Craik; Raymond Klein; and Mythili Viswanathan. 2004. Bilingualism, aging, and cognitive control: Evidence from the Simon Task. Psychology and Aging 19.290-303. 
Blankmeyer Burke, Teresa; Poorna Kushalnagar; Gaurav Mathur; Donna Jo Napoli; Christian Rathmann; and Kirk Vangilder. 2011. The language needs of deaf and hard-of-hearing infants and children: Information for spiritual leaders and communities. Journal of Religion, Disability \& Health 15.272-95.

Borkowski, Gerd; Henning Hildmann; and Thomas Stark. 2002. Surgical aspects of cochlear implantation in young and very young children. Cochlear implants: An update, ed. by Takeshi Kubo, Y. Takahashi, and Takako Iwaki, 223-26. The Hague: Kugler.

Bowd, Alan D. 2005. Otitis media: Health and social consequences for aboriginal youth in Canada's north. International Journal of Circumpolar Health 64.5-15.

Boyes Braem, Penny. 1999. Rhythmic temporal patterns in the signing of deaf early and late learners of Swiss German Sign Language. Language and Speech 42.177-208.

Boyes Braem, Penny, and Christian Rathmann. 2010. Transmission of sign languages in Northern Europe. In Brentari, 19-45.

Brentari, Diane (ed.) 2010. Sign languages. Cambridge: Cambridge University Press.

Broesterhuizen, Marcel, and K. U. Leuven. 2008. Worlds of difference: An ethical analysis of choices in the field of deafness. Ethical Perspectives: Journal of the European Ethics Network 15.103-31.

**Burkholder, Rose A., and David B. Pisoni. 2006. Working memory capacity, verbal rehearsal speed and scanning in deaf children with cochlear implants. In Spencer \& Marschark, 328-57.

***Chamberlain, Charlene, and Rachel I. Mayberry. 2008. American Sign Language syntactic and narrative comprehension in skilled and less skilled readers: Bilingual and bimodal evidence for the linguistic basis of reading. Applied Psycholinguistics 29.36788.

Christiansen, John B., and Irene W. Leigh. 2002. Cochlear implants in children: Ethics and choices. Washington, DC: Gallaudet University Press.

Cohen, Noel L., and J. Thomas Roland, JR. 2006. Complications of cochlear implant surgery. Cochlear implants, 2nd edn., ed. by Susan B. Waltzman and J. Thomas Roland, Jr., 205-13. New York: Thieme Medical Publishers.

Cohn, Jonathan. 2011. The two year window: The new science of babies and brains - and how it could revolutionize the fight against poverty. The New Republic, November 9, 2011. Online: http://www.newrepublic.com/article/economy/magazine/97268/the-two -year-window, accessed September 12, 2012.

Convention on the Rights of Persons with Disabilities. 2006. United Nations. Online: http://www.un.org/disabilities/convention/conventionfull.shtml.

Corina, DAVID. 1998. The processing of sign language: Evidence from aphasia. Handbook of neurolinguistics, ed. by Harry A. Whitaker and Brigitte Stemmer, 313-29. San Diego: Academic Press.

Cormier, Kearsy; Adam Schembri; David Vinson; and Eleni Orfanidou. 2012. First language acquisition differs from second language acquisition in prelingually deaf signers: Evidence from sensitivity to grammaticality judgement in British Sign Language. Cognition 124.50-65.

Courtin, Cyril. 2000. The impact of sign language on the cognitive development of deaf children: The case of theories of mind. Journal of Deaf Studies and Deaf Education 5.266-76.

Courtin, CyriL. 2010. A critical period for the acquisition of the theory of mind? Clues from homesigners. Deaf around the world: The impact of language, ed. by Gaurav Mathur and Donna Jo Napoli, 184-93. Oxford: Oxford University Press.

Courtin, Cyril, and Anne-Marie Melot. 2005. Metacognitive development of deaf children: Lessons from the appearance-Reality and false belief tasks. Developmental Science 8.16-25.

Courtin, Cyril; Anne-Marie Melot; and Denis Corroyer. 2008. Achieving efficient learning: Why theory of mind is essential for deaf children ... and their teachers. In Marschark \& Hauser, 102-30.

**Crouch, Robert A. 1999. Letting the deaf be deaf: Reconsidering the use of cochlear implants in prelingually deaf children. Meaning and medicine: A reader in the philosophy of health care, ed. by James Lindemann Nelson and Hilde Lindemann Nelson, 360-70. London: Routledge. 
Cummins, Jim, and M. Gulustan. 1974. Bilingual education and cognition. Alberta Journal of Educational Research 20.259-66.

Curtiss, Susan. 1977. Genie: A psycholinguistic study of a modern-day 'wild child'. New York: Academic Press.

CURTISS, SusAn. 1994. Language as a cognitive system: Its independence and selective vulnerability. Noam Chomsky: Critical assessments, vol. 4, ed. by Carlos Otero, 211-55. London: Routledge.

Davidson, Kathryn; Diane Lillo-Martin; and Deborah Chen Pichler. 2014. Spoken English language development among native signing children with cochlear implants. Journal of Deaf Studies and Deaf Education 19.2.238-50.

Department of Health and Human Services, Centers for Disease Control and Prevention, Early Hearing Detection \& Intervention (EHDi) Program. 2009. Organizational recommendations and screening guidelines. Online: http://www.cdc .gov/NCBDDD/ehdi/ddscreen.htm, accessed September 5, 2009.

Drury, Stacy S.; Katherine P. Theall; M. M. Gleason; Anna T. Smyke; Immaculata De Vivo; J. Y. Y. Wong; N. A. Fox; Charles H. Zeanah; and Charles A. Nelson. 2012. Telomere length and early severe social deprivation: Linking early adversity and cellular aging. Molecular Psychiatry 17.719-27.

Early Hearing Detection and Intervention Information \& Resource Center, National Center for Hearing Assessment \& Management. 2004. 2004 State EHDI survey. Online: http://www.infanthearing.org/survey/2004statesurvey/index.html, accessed June 10, 2008.

Elwyn, Glyn; Amy Lloyd; Natalie Joseph-Williams; Emma Cording; Richard Thomson; Marie-Anne Durand; and Adrian Edwards. 2013. Option grids: Shared decision making made easier. Patient Education and Counseling 90.207-12.

EMMOREY, Karen. 1991. Repetition priming with aspect and agreement morphology in American Sign Language. Journal of Psycholinguistic Research 20.365-88.

EMmorey, KAREN. 2001. Language, cognition and the brain: Insights from sign language research. Mahwah, NJ: Lawrence Erlbaum.

EMmorey, KAREN, and DAvid CoRINA. 1990. Lexical recognition in sign language: Effects of phonetic structure and morphology. Perceptual and Motor Skills 71.1227-52.

Figueras, BerTa; LindSEy EdWARds; and DaWn LANGDON. 2008. Executive function and language in deaf children. Journal of Deaf Studies and Deaf Education 13.362-77.

**Fink, Nancy E.; Nae-Yuh Wang; Jiovani Visaya; John K. Niparko; Alexandra Quittner; Laurie S. Eisenberg; and Emily A. Tobey. 2007. Childhood development after cochlear implantation (CDaCI) study: Design and baseline characteristics. Cochlear Implants International 8.92-116.

***FISCHER, SusAN. 1998. Critical periods for language acquisition: Consequences for deaf education. Issues unresolved: New perspectives on language and deaf education, ed. by Amatzia Weisel, 9-26. Washington, DC: Gallaudet University Press.

Galvan, DenNis. 1999. Differences in the use of American Sign Language morphology by deaf children: Implication for parents and teachers. American Annals of the Deaf 144. $320-24$.

Garg, Suneela; Ritesh Singh; Shelly Chadha; and Arun Kuman Agarwal. 2011. Cochlear implantation in India: A public health perspective. Indian Journal of Medical Sciences 65.116-20.

**GeERs, AnN E. 2006. The process and early outcomes of cochlear implantation by three years of age. In Spencer \& Marschark, 271-97.

**Geers, Ann E.; Emily Tobey; Jean Moog; and Chris Brenner. 2008. Long-term outcomes of cochlear implantation in the preschool years: From elementary grades to high school. International Journal of Audiology 47.21-30.

Gerich, JoAChim, and Johannes Fellinger. 2012. Effects of social networks on the quality of life in an elder and middle-aged deaf community sample. Journal of Deaf Studies and Deaf Education 17.102-15.

**Giraud, Anne-Lise, and Hyo-Jeong Lee. 2007. Predicting cochlear implant outcome from brain organization in the deaf. Restorative Neurology and Neuroscience 25.381-90.

Goldin-Meadow, Susan. 2003. The resilience of language: What gesture creation in deaf children can tell us about how all children learn language. New York: Psychology Press. 
Goldin-Meadow, Susan. 2005. What language creation in the manual modality tells us about the foundations of language. The Linguistic Review 22.199-225.

Goorhuis-Brouwer, Sieneke M. 1976. Enkele opmerkingen over afasie bij kinderen. Logopedie en Foniatrie 48.69-77.

Grant, SusAn E. 2008. The silent debate: The controversy over the cochlear implant and how it is changing the Deaf community. Los Angeles: University of Southern California Press.

**Green, Kevin M. J.; Y. M. Bhatt; Deborah J. Mawman; Martin P. O’Driscoll; Shakeel R. Saeed; Richard T. Ramsden; and M. W. Green. 2007. Predictors of audiological outcome following cochlear implantation in adults. Cochlear Implants International 8.1-11.

Gregory, Susan. 1995. Deaf children and their families. New York: George Allen \& Unwin.

Grimshaw, Gina M.; Ana Adelstein; M. Philip Bryden; and G. E. MacKinnon. 1998. First-language acquisition in adolescence: Evidence for a critical period for verbal language development. Brain and Language 63.237-55.

Hall, James W., and Kristin N. Johnston. 2009. Diagnostic audiology, hearing instruments and aural habilitation. In Snow \& Wackym, 115-30.

Hauser, Peter C.; Amanda O'Hearn; Michael McKee; Anne Steider; and Denise THEw. 2010. Deaf epistemology: Deafhood and deafness. American Annals of the Deaf $154.486-92$.

Haynes, Scott, and Maureen Linden. 2012. Workplace accommodations and unmet needs specific to individuals who are deaf or hard of hearing. Disability and Rehabilitation: Assistive Technology 7.408-15.

Helmuth, Laura. 2001. From the mouths (and hands) of babes. Science 293.1758-59.

***Hermans, Daan; Harry Knoors; Ellen Ormel; and Ludo Verhoeven. 2008. The relationship between the reading and signing skills of deaf children in bilingual education programs. Journal of Deaf Studies and Deaf Education 13.518-30.

**Hicks, Candace B., and Anne Marie Tharpe. 2002. Listening effort and fatigue in school age children with and without hearing loss. Journal of Speech, Hearing, and Language Research 45.573-84.

Hudson, Carla, and Elissa Newport. 2009. Getting it right by getting it wrong: When learners change languages. Cognitive Psychology 59.30-66.

Humphries, Tom. 2013. Schooling in American Sign Language: A paradigm shift from a deficit model to a bilingual model in deaf education. Berkeley Review of Education 4.7-33.

Humphries, Tom; Poorna Kushalnagar; Gaurav Mathur; Donna Jo Napoli; Carol Padden; Christian Rathmann; and Scott Smith. 2012a. Language acquisition for deaf children: Reducing the harms of zero tolerance to the use of alternative approaches. Harm Reduction Journal 9.16. Online: http://www.harmreductionjournal .com/content/9/1/16. [German translation: Spracherwerb für gehörlose Kinder: Minderung der durch fehlende Toleranz entstehenden Schäden - hin zum Einsatz alternativer Ansätze. Das Zeichen 26.91.334-47, 2012.]

Humphries, Tom; Poorna Kushalnagar; Gaurav Mathur; Donna Jo Napoli; Carol Padden; Christian Rathmann; and Scott Smith. 2012b. Cochlear implants and the right to language: Ethical considerations, the ideal situation, and practical measures toward reaching the ideal. Cochlear implant research updates, ed. by Cila Umat and Rinze Anthony Tange, 193-213. Rijeka: InTech. Online: http://cdn.intechopen.com /pdfs-wm/36348.pdf.

Humphries, Tom; Poorna Kushalnagar; Gaurav Mathur; Donna Jo Napoli; Carol Padden; Christian Rathmann; and Scott Smith. 2014. Bilingualism: A pearl to overcome certain perils of cochlear implants. Journal of Medical Speech-Language Pathology 21.107-25.

Humphries, Tom; Raja Kushalnagar; Gaurav Mathur; Donna Jo Napoli; Carol Padden; Christian Rathmann; and Scott Smith. 2013. The right to language. The Journal of Law, Medicine \& Ethics (Special issue: Symposium: Human Rights and Disability) 41.872-84.

Iezzoni, Lisa I.; Bonnie L. O'Day; Mary Killeen; and Heather Harker. 2004. Communicating about health care: Observations from persons who are deaf or hard of hearing. Annals of Internal Medicine 140.356-62. 
JAUHiainen, TAPANI. 2001. Hearing impaired children in developing countries. Scandinavian Audiology 30.83-84.

Johnson, JACQueline S., and Elissa L. NewPort. 1989. Critical period effects in second language learning: The influence of maturational state on the acquisition of English as a second language. Cognitive Psychology 21.60-99.

Johnston, Trevor A. 2006. Response to comment. Sign Language Studies 6.225-43.

Joint Committee on Infant Hearing. 2007. Year 2007 position statement: Principles and guidelines for early hearing detection and intervention programs. Pediatrics $120.898-$ 921.

Klatter-Folmer, Jetske; Roeland van Hout; Esther Kolen; and Ludo Verhoeven. 2006. Language development in deaf children's interactions with Deaf and hearing adults: A Dutch longitudinal study. Journal of Deaf Studies and Deaf Education 11. $238-51$.

Kleimenov, Mikhail, and Stanislav Shamkov. 2005. Criminal transportation of persons: Trends and recommendations. Human traffic and transnational crime: Eurasian and American perspectives, ed. by Sally Stoecker and Louise Shelley, 29-46. Lanham, MD: Rowman \& Littlefield.

KnOORS, Harry, and Marc Marschark. 2012. Language planning for the 21st century: Revisiting bilingual language policy for deaf children. Journal of Deaf Studies and Deaf Education 17.291-305.

Knutson, John F.; Christina R. Johnson; and Patricia M. Sullivan. 2004. Disciplinary choices of mothers of deaf children and mothers of normally hearing children. Child Abuse \& Neglect 28.925-37.

Kozak, Frederick K.; Juan C. Ospina; and Marcela Fandino. 2009. Investigation of sensorineural hearing loss. Paper presented at Curso Internacional de Otorinolaringologia Pediatrica. Online: http://www.cpnlac.org/memoriasacademicasinter americano2009/files/Frederick\%20K.\%20Kozak\%20-\%20Investigation \%20of\%20 SNHL\%20Monterey\%20Talk\%20Jul.pdf.

Kral, AndreJ, and Gerard M. O'Donoghue. 2011. Profound deafness in childhood (Correspondence: The authors reply). The New England Journal of Medicine 364.485.

Krashen, Stephen D. 1981. Second language acquisition and second language learning. Oxford: Pergamon.

Krausneker, Verena. 2008. The protection and promotion of sign languages and the rights of their users in Council of Europe member states: Needs analysis. Strasbourg: Council of Europe. Online: http://www.coe.int/t/DG3/Disability/Source/Report_Sign languages_final.pdf.

Kushalnagar, Poorna; H. Julia Hannay; and Arturo E. Hernandez. 2010. Bilingualism and attention: A study of balanced and unbalanced deaf users of American Sign Language and English. Journal of Deaf Studies and Deaf Education 15.263-73.

Kushalnagar, Poorna; Gaurav Mathur; Christopher J. Moreland; Donna Jo Napoli; Wendy Osterling; Carol Padden; and Christian Rathmann. 2010. Infants and children with hearing loss need early language access. Journal of Clinical Ethics 21.143-54.

Kushalnagar, Poorna; Tari D. Topolski; Brenda Schick; Todd Edwards; Anne Skalicky; and Donald L. Patrick. 2011. Mode of communication, perceived level of understanding and perceived quality of life in youth who are deaf or hard-of-hearing. Journal of Deaf Studies and Deaf Education 16.512-23.

Kvam, Marit Hoem. 2004. Sexual abuse of deaf children: A retrospective analysis of the prevalence and characteristics of childhood sexual abuse among Deaf adults in Norway. Child Abuse \& Neglect 28.241-51.

Lane, Harlan; Robert Hoffmeister; and Benjamin Bahan. 1996. A journey into the Deaf-world. San Diego: Dawn Sign.

Leigh, Irene W. 2009. Identity and deafness. Oxford: Oxford University Press.

LENNEBERG, ERIC. 1964. The capacity of language acquisition. The structure of language, ed. by Jerry Fodor and Jerry Katz, 579-603. Englewood Cliffs, NJ: Prentice Hall.

LENNEBERG, ERIC. 1967. Biological foundations of language. New York: Wiley.

**Leung, Janice; Nae-Yuh Wang; Jennifer D. Yeagle; Jill Chinnici; Stephen Bowditch; Howard W. Francis; and John K. Niparko. 2005. Predictive models for cochlear implantation in elderly candidates. Archives of Otolaryngology-Head and Neck Surgery 131.1049-54. 
Lightbown, Patsy, and Nina Spada. 2006. How languages are learned. 3rd edn. Oxford: Oxford University Press.

Lillo-Martin, Diane. 1999. Modality effects and modularity in language acquisition: The acquisition of American Sign Language. Handbook of child language acquisition, ed. by William C. Ritchie and Tej K. Bhatia, 531-67. San Diego: Academic Press.

LuK, Gigi; ERIC De SA; and ElLEN BiAlystoK. 2011. Is there a relation between onset age of bilingualism and enhancement of cognitive control? Bilingualism: Language and Cognition 14.588-95.

Luterman, David. 1979. Counseling parents of hearing-impaired children. Boston: Little, Brown \& Co.

***MacSweeney, Mairead. 1998. Cognition and deafness. Issues in deaf education, ed. by Susan Gregory, Pamela Knight, Wendy McCracken, Stephen Powers, and Linda Watson, 20-27. London: David Fulton.

Marlowe, Andrea L.; Jill E. Chinnici; Alejandro Rivas; John K. Niparko; and HowARD W. Francis. 2010. Revision cochlear implant surgery in children: The Johns Hopkins experience. Otology \& Neurotology 31.74-82.

Marschark, Marc. 2009. Raising and educating a deaf child: A comprehensive guide to the choices, controversies, and decisions faced by parents and educators. Oxford: Oxford University Press.

Marschark, Marc, and Peter C. Hauser (eds.) 2008. Deaf cognition: Foundations and outcomes. New York: Oxford University Press.

**Marschark, Marc; Cathy Rhoten; and Megan Fabich. 2007. Effects of cochlear implants on children's reading and academic achievement. Journal of Deaf Studies and Deaf Education 12.269-82.

**Marschark, Marc; Thomastine Sarchet; Cathy Rhoten; and Megan Zupan. 2010. Will cochlear implants close the reading achievement gap for deaf students? In Marschark \& Spencer 2010, 127-43.

Marschark, Marc, and Patricia E. Spencer (eds.) 2003. The Oxford handbook of deaf studies, language, and education. Oxford: Oxford University Press.

Marschark, Marc, and Patricia E. Spencer (eds.) 2010. The Oxford handbook of deaf studies, language, and education, vol. 2. 2nd edn. Oxford: Oxford University Press.

Marschark, Marc, and Patricia E. SPencer (eds.) 2011. The Oxford handbook of deaf studies, language, and education, vol. 1. 2nd edn. Oxford: Oxford University Press.

**Martin, Daniela; Yael Bat-Chava; Anil Lalwani; and Susan B. Waltzman. 2010. Peer relationships of deaf children with cochlear implants: Predictors of peer entry and peer interaction success. Journal of Deaf Studies and Deaf Education 16.108-20.

Martins, Isabel P. 2004. Persistent acquired childhood aphasia. Neurogenic language disorders in children, ed. by Franco Fabro, 231-51. Amsterdam: Elsevier.

MAYBERRY, RACHEL. 1994. The importance of childhood to language acquisition: Evidence from American Sign Language. The development of speech perception: The transition from speech sounds to words, ed. by Judith Goodman and Howard C. Nusbaum, 57-90. Cambridge, MA: MIT Press.

MAYBERRY, RACHEL. 1998. The critical period for language acquisition and the deaf child's language comprehension: A psycholinguistic approach. Bulletin d'Audiophonologie: Annales Scientifiques de L'Université de Franche-Comte 15.349-58.

MayberRy, Rachel, and Ellen B. Eichen. 1991. The long-lasting advantage of learning sign language in childhood: Another look at the critical period for language acquisition. Journal of Memory and Language 30.486-512.

MAYBerRy, Rachel, and SusAn Fischer. 1989. Looking through phonological shape to lexical meaning: The bottleneck of non-native sign language processing. Memory and Cognition 17.740-54.

***Mayer, Connie, and C. Tane Akamatsu. 2003. Bilingualism and literacy. In Marschark \& Spencer 2003, 136-50.

***MCGuINNESS, DiANe. 2006. Language development and learning to read: The scientific study of how language development affects reading skill. Cambridge, MA: MIT Press.

McJunkin, Jonathan, and Anita Jeyakumar. 2010. Complications in pediatric cochlear implants. American Journal of Otolaryngology 31.110-13.

McKee, Michael M.; Steve L. Barnett; Robert C. Block; and Thomas A. Pearson. 2011. Impact of communication on preventive services among deaf American Sign Language users. American Journal of Preventive Medicine 41.75-79. 
McKee, Michael M.; Deirdre Schlehofer; Jessica Cuculick; Matthew Starr; Scott Smith; and NAnCy P. Chin. 2011. Perceptions of cardiovascular health in an underserved community of deaf adults using American Sign Language. Disability and Health Journal 4.192-97.

Meader, Helen E., and Philip Zazove. 2005. Health care interactions with Deaf culture. Journal of the American Board of Family Practice 18.218-22.

Meier, Richard, and Elissa NewPort. 1990. Out of the hands of babes: On a possible sign advantage. Language 66.1-23.

Mellon, NANCY K. 2009. Parental response to the diagnosis of hearing loss. In Niparko, $147-49$.

Mesch, Johanna. 2001. Tactile sign language: Turn taking and questions in signed conversations of deaf-blind people. Camarillo, CA: Signum.

Meshik, Xenia; Timothy A. Holden; Richard A. Chole; Timothy E. Hullar. 2010. Optimal cochlear implant insertion vectors. Otology \& Neurotology 31.1.58-63.

Miller, Katrina R.; McCay Vernon; and Michele E. Capella. 2005. Violent offenders in a deaf prison population. Journal of Deaf Studies and Deaf Education 10.41725.

**Miyamato, Richard T.; Karen Iler Kirk; Amy M. Robbins; Susan Todd; Allison RILEY; and DAVID B. PISONI. 1997. Speech perception and speech intelligibility in children with multichannel cochlear implants. Advances in Otorhinolaryngology 52.198203.

Moeller, Mary Pat; Karl R. White; and Lenore Shisler. 2006. Primary care physicians' knowledge, attitudes, and practices related to newborn hearing screening. Pediatrics $118.1357-70$.

Moores, Donald. 2001. Educating the deaf: Psychology, principles, and practices. Boston: Houghton Mifflin.

Morford, Jill, and Barbara Hänel-Faulhaber. 2011. Homesigners as late learners: Connecting the dots from delayed acquisition in childhood to sign language processing in adulthood. Language and Linguistics Compass 5.535-37.

Morgan, Gary, and Judy Kegl. 2006. Nicaraguan Sign Language and theory of mind: The issue of critical period and abilities. Journal of Child Psychology and Psychiatry 47.811-19.

Munoz-Baell, Irma M.; Carlos Alvarez-Dardet; Maria Teresa Ruiz; R. Ortiz; M. L. Esteban; and Emilio Ferreiro. 2008. Preventing disability through understanding international megatrends in deaf bilingual education. Journal of Epidemiology and Community Heath 62.131-37.

Musani, Mohammed Ayub; Faheem Ahmed Khan; Abdul Rauf; and Murtaza Ahsan. 2011. Frequency and causes of hearing impairment in tertiary care center. Journal of Pakistan Medical Association 61.141-44.

National Institutes of Health. May 2011. It's important to have your baby's hearing screened. (NIH publication no. 11-4968.) Bethesda, MD: National Institute on Deafness and Other Communication Disorders. Online: https://www.nidcd.nih.gov/health /hearing/pages/screened.aspx.

Nelson, Charles; Nathan Fox; Charles Zeanah; and Dana Johnson. 2007. Caring for orphaned, abandoned and maltreated children: Bucharest Early Intervention Project. Presentation at the Better Care Network Discussion Day, Washington, DC, January 10, 2007. Online: http://www.unicef.bg/public/images/tinybrowser/upload/PPT\%20BEIP \%20Group\%20for\%20website.pdf, accessed September 12, 2012.

Neville, Helen. 1995. Developmental specificity in neurocognitive development in humans. The cognitive neurosciences, ed. by Michael S. Gazzaniga, 219-31. Cambridge, MA: MIT Press.

NewPort, Elissa L. 1990. Maturational constraints on language learning. Cognitive Science 14.11-28.

NewPORT, Elissa L. 1991. Contrasting conceptions of the critical period for language. The epigenesis of mind: Essays on biology and cognition, ed. by Susan Carey and Rochel Gelman, 111-30. Hillsdale, NJ: Lawrence Erlbaum.

Newport, Elissa L.; Daphne Bavelier; and Helen J. Neville. 2001. Critical thinking about critical periods: Perspectives on a critical period for language acquisition. Language, brain and cognitive development: Essays in honor of Jacques Mehler, ed. by Emmanuel Dupoux, 481-502. Cambridge, MA: MIT Press. 
Newport, Elissa L., and Richard Meier. 1985. The acquisition of American Sign Language. The crosslinguistic study of language acquisition, vol. 1, ed. by Dan Slobin, 881-938. Hillsdale, NJ: Lawrence Erlbaum.

Newport, Elissa L., and Ted Supalla. 1987. A critical period effect in the acquisition of a primary language. Rochester: University of Rochester, MS.

**Nicholas, Johanna Grant, and Ann E. Geers. 2007. Will they catch up? The role of age at cochlear implantation in the spoken language development of children with severe to profound hearing loss. Journal of Speech, Language, and Hearing Research 50. $1048-62$.

Niparko, John K. (ed.) 2009. Cochlear implants: Principles \& practices. 2nd edn. Philadelphia: Lippincott Williams \& Wilkins.

Northern, Jerry L., and Marion P. Downs. 2002. Hearing in children. 6th edn. Philadelphia: Lippincott Williams \& Wilkins.

Oghalai, John S.; Lei Chen; Megan L. Brennan; Ross Tonini; and Spiros Manolidis. 2002. Neonatal hearing loss in the indigent. The Laryngoscope 112.281-86.

Oliva, Gina A. 2004. Alone in the mainstream: A Deaf woman remembers public school. Washington, DC: Gallaudet University Press.

Olusanya, Bolajoko O.; Sheila L. Wirz; and Linda M. Luxon. 2008. Communitybased infant hearing screening for early detection of permanent hearing loss in Lagos, Nigeria: A cross-sectional study. Bulletin of the World Health Organization 86.956-63.

**O'Reilly, Robert C.; Amanda J. Mangiardi; and H. Timothy Bunnell. 2008. Cochlear implants. Access: Multiple avenues for deaf people, ed. by Doreen DeLuca, Irene W. Leigh, Kristin A. Lindgren, and Donna Jo Napoli, 38-74. Washington, DC: Gallaudet University Press.

Padden, Carol, and Tom Humphries. 2005. Inside Deaf culture. Cambridge, MA: Harvard University Press.

***Padden, Carol, and Claire Ramsey. 2000. American Sign Language and reading ability in deaf children. Language acquisition by eye, ed. by Charlene Chamberlain, Jill P. Morford, and Rachel Mayberry, 165-89. Mahwah, NJ: Lawrence Erlbaum.

**Papsin, Blake C.; Claudine Gysin; Nina Picton; Julian Nedzelski; and Robert V. HARRISON. 2000. Speech perception outcome measures in prelingually deaf children up to four years after cochlear implantation. Annals of Otology, Rhinology, and Laryngology $109.38-42$.

Paqarkar, Waheeda; Maria Bitner-Glindzicz; Jeffrey Knight; and Tony SiriMANNA. 2006. Late postnatal onset of hearing loss due to GJB2 mutations. International Journal of Pediatric Otorhinolaryngology 70.1119-24.

***Paul, Peter V. 2003. Processes and components of reading. In Marschark \& Spencer 2003, 97-109.

**Peterson, Nathaniel R.; David B. Pisoni; and Richard T. Miyamoto. 2010. Cochlear implants and spoken language processing abilities: Review and assessment of the literature. Restorative Neurology and Neuroscience 28.237-50.

Petitto, Laura-AnN. 1998. On the biological, environmental and neurogenetic factors determining early language acquisition: Evidence from signed and spoken languages. Bulletin D'Audiophonologie 14.337-48.

Petitto, Laura-Ann, and Paula F. Marentette. 1991. Babbling in the manual mode: Evidence for the ontogeny of language. Science 251.1493-96.

Pfau, Roland; Marcus Steinbach; and Bencie Woll (eds.) 2012. Sign language: An international handbook. Berlin: De Gruyter Mouton.

**Pisoni, David B., and Miranda Cleary. 2003. Measures of working memory span and verbal rehearsal speed in deaf children after cochlear implantation. Ear and Hearing 24.106S-120S.

**Pisoni, David B., and Miranda Cleary. 2004. Learning, memory, and cognitive processes in deaf children following cochlear implantation. Cochlear implants: Auditory prostheses and electrical hearing, ed. by Fan-Gang Zeng, Arthur N. Popper, and Richard R. Fay, 377-426. New York: Springer.

**Pisoni, David B.; Miranda Cleary; Ann E. Geers; and Emily A. Tobey. 2000. Individual differences in effectiveness of cochlear implants in prelingually deaf children: Some new process measures of performance. Volta Review 101.111-64. 
**Pisoni, David B.; Christopher M. Conway; William G. Kronenberger; David L. Horn; Jennifer Karpicke; and Shirley C. Henning. 2008. Efficacy and effectiveness of cochlear implants in deaf children. In Marschark \& Hauser, 52-101.

**Pisoni, David B., and AnN E. Geers. 2001. Working memory in deaf children with cochlear implants: Correlations between digit span and measures of spoken language processing. Annals of Otology, Rhinology \& Laryngology 109.92-93.

Poizner, Howard; Edward Klima; and Ursula Bellugi. 1987. What the hands reveal about the brain. Cambridge, MA: MIT Press.

Porter, AnN, and Sisira EdiRIPPUlige. 2007. Parents of deaf children seeking hearing loss-related information on the internet: The Australian experience. Journal of Deaf Studies and Deaf Education 12.518-29.

Prince, Cheryl B.; Lloyd Miyashiro; Yusnita Weirather; and Patricia Heu. 2003. Epidemiology of early hearing loss detection in Hawaii. Pediatrics 111.1202-6.

Prinz, Philip M., and Michael Strong. 1998. ASL proficiency and English literacy within a bilingual deaf education model of instruction. Topics in Language Disorders $18.47-60$.

Ramsey, Claire L. 1997. Deaf children in public schools: Placement, context and consequences, vol. 3. Washington, DC: Gallaudet University Press.

Rashid, Khadijat; Poorna Kushalnagar; and Raja Kushalnagar. 2011. How deaf adult signers experience implants: Some preliminary conclusions. Cochlear implants: Evolving perspectives, ed. by Raylene Paludneviciene and Irene Leigh, 45-59. Washington, DC: Gallaudet University Press.

Reddy, M. Vishnu Vardhan; L. Hema Bindu; P. Usha Rani; and P. P. Reddy. 2006. Postnatal risk factors of congenital hearing impairment: Otitis media, head injuries, and convulsions. International Journal of Human Genetics 6.191-93.

Remmel, Ethan, and Kimberly Peters. 2009. Theory of mind and language in children with cochlear implants. Journal of Deaf Studies and Deaf Education 14.218-36.

**Robbins, Amy McConkey; Mario Svirsky; and Karen Iler Kirk. 1997. Children with implants can speak, but can they communicate? Otolaryngology_Head and Neck Surgery $117.115-60$.

RÖNNBERG, JERKER. 2003. Working memory, neuroscience, and language: Evidence from deaf and hard-of-hearing individuals. In Marschark \& Spencer 2003, 478-90.

Rubin, LoRry G., and Blake PAPSIN. 2010. Cochlear implants in children: Surgical site infections and prevention and treatment of acute otitis media and meningitis. Pediatrics $126.381-91$.

Sandler, Wendy, and Diane Lillo-Martin. 2006. Sign language and linguistic universals. Cambridge: Cambridge University Press.

Santarelli, Rosamaria; Roberta De Filippi; Elisabetta Genovese; and Edoardo ArSLAN. 2008. Cochlear implantation outcome in prelingually deafened young adults. $A u$ diology and Neuro-Otology 13.257-65.

**Sarant, Julia Z.; Peter J. Blamey; Richard C. Dowell; Graeme M. Clark; and W. P. R. GiBSON. 2001. Variation in speech perception scores among children with cochlear implants. Ear and Hearing 22.18-28.

SAunders, James, and David Barrs. 2011. Cochlear implantation in developing countries as humanitarian service: Physician attitudes and recommendations for best practice. Otolaryngology — Head and Neck Surgery 145.74-79.

***SCHICK, BRENDA. 2003. The development of American Sign Language and manually coded English systems. In Marschark \& Spencer 2003, 219-31.

Schick, Brenda; Peter de Villiers; Jill de Villiers; and Robert Hoffmeister. 2007. Language and theory of mind: A study of deaf children. Child Development 78.376-96.

Schick, Brenda; Marc Marschark; and Patricia Spencer. 2006. Advances in the sign language development of deaf children. New York: Oxford University Press.

Schnell-Inderst, Petra; Silke Kunze; Franz Hessel; Eva Grill; Uwe Siebert; AnDreas Nickisch; Hubertus Von Voss; and JÜrgen WaSem. 2006. Hörscreening für Neugeborene-Update. (Schriftenreihe health technology assessment 47.) Cologne: Deutsches Institut für Medizinische Dokumentation und Information.

Shattuck, Roger. 1980. The forbidden experiment: The story of the wild boy of Aveyron. New York: Farrar, Straus and Giroux. 
Singleton, Jenny, and Elissa Newport. 2004. When learners surpass their models: The acquisition of American Sign Language from inconsistent input. Cognitive Psychology 49.370-407.

Skinner, Margaret W.; Laura K. Holden; Lesley A. Whitford; Kerrie L. Plant; Colleen Psarros; and Timothy A. Holden. 2002. Speech recognition with the nucleus 24 SPEAK, ACE, and CIS speech coding strategies in newly implanted adults. Ear and Hearing 23.207-23.

Skotara, Nils; Uta Salden; Monique Kügow; Barbara Hänel-Faulhaber; and BRIGITTE RöDER. 2012. The influence of language deprivation in early childhood on L2 processing: An ERP comparison of deaf native signers and deaf signers with a delayed language acquisition. BMC Neuroscience 13.44.

Snow, Catherine, and Marian Hoefnagel-Höhle. 1978. The critical period for language acquisition: Evidence from second language learning. Child Development 49. $1114-28$

SnOW, JAmes B., JR., and P. Ashley WaCKym (eds.) 2009. Ballenger's otorhinolaryngology 17: Head and neck surgery. Shelton, CT: People's Medical Publishing House.

Spahn, Claudia; Bernhard Richter; Thorsten Burger; Erwin Löhle; and Michael WIRSCHING. 2003. A comparison between parents of children with cochlear implants and parents of children with hearing aids regarding parental distress and treatment expectations. International Journal of Pediatric Otorhinolaryngology 67.947-55.

SPenCER, Patricia E. 1993. The expressive communication of hearing mothers and deaf infants. American Annals of the Deaf 138.275-83.

SPencer, Patricia E., and Marc Marschark (eds.) 2006. Advances in the spoken language development of deaf and hard-of-hearing children. Oxford: Oxford University Press.

SPIVAK, LYNN G. 2007. Neonatal hearing screening, follow-up, and diagnosis. Audiology diagnosis, 2nd edn., ed. by Ross J. Roeser, Michael Valente, and Holly Hosford-Dunn, 497-513. New York: Thieme Medical Publishers.

Steenerson, Ronald Leif; Gaye W. Cronin; and Lucinda B. Gary. 2001. Vertigo after cochlear implantation. Otology \& Neurotology 22.842-43.

Steinberg, Annie G.; Vicki Joy Sullivan; and Ruth C. Loew. 1998. Cultural and linguistic barriers to mental health service access: The deaf consumer's perspective. American Journal of Psychiatry 155.982-84.

Stinson, Michael S., and Yufang Liu. 1999. Participation of deaf and hard-of-hearing students in classes with hearing students. Journal of Deaf Studies and Deaf Education 4.191-202.

***Strong, Michael, and Philip Prinz. 2000. Is American Sign Language skill related to English literacy? Language acquisition by eye, ed. by Charlene Chamberlain, Jill Morford, and Rachel Mayberry, 131-42. Mahwah, NJ: Lawrence Erlbaum.

Sullivan, Patricia M., and John F. Knutson. 2000. Maltreatment and disabilities: A population-based epidemiological study. Child Abuse \& Neglect 24.1257-73.

Svirsky, Mario A.; Su Wooi Teoh; and Heidi S. Neuburger. 2004. Development of language and speech perception in congenitally, profoundly deaf children as a function of age at cochlear implantation. Audiology and Neuro-Otology 9.224-33.

Szagun, Gisela. 2008. The younger the better? Variability in language development of young German-speaking children with cochlear implants. Proceedings of the Child Language Seminar 2007-30th Anniversary, ed. by Theodoros Marinis, Angeliki Papangeli, and Vesna Stojanovik, 183-94. Reading: University of Reading Press.

The Canadian Hearing Society. 2005. Response of the Canadian Hearing Society to the Standing Committee on Social Affairs, Science and Technology: Challenges facing deaf, deafened, and hard of hearing individuals with mental health issues. Toronto: The Canadian Hearing Society. Online: http://www.deafontario.ca/article-2011-03-13-CI -by-snoddon.html.

Thom, Joshua J.; Matthew L. Carlson; Michael D. Olson; Brian A. NefF; Charles W. Beatty; George W. Facer; and Colin L. W. Driscoll. 2013. The prevalence and clinical course of facial nerve paresis following cochlear implant surgery. The Laryngoscope 123.1000-1004.

**Thoutenhoofd, Ernst D.; Sue Archbold; Sue Gregory; Mark E. Lutman; Thomas Nikolopoulos; and Tracey H. Sach. 2005. Paediatric cochlear implantation: Evaluating outcomes. London: Whurr. 
**Tobey, Emily A.; Ann E. Geers; Chris Brenner; Dianne Altuna; and Gretchen GABBERT. 2003. Factors associated with development of speech production skills in children implanted by the age of five. Ear and Hearing 24.36S-46S.

ToBin, Henry (ed.) 1995. Rehabilitation research and development service: Practical hearing aid selection and fitting. Baltimore: Department of Veterans Affairs.

Tomblin, J. Bruce; Brittan A. Barker; Linda J. Spencer; and Xuyang Zhang. 2005. The effect of age at cochlear implant initial stimulation on expressive language growth in infants and toddlers. Journal of Speech, Language, and Hearing Research 48.85367.

Tucci, Debara L.; Michael H. Merson; and Blake S. Wilson. 2010. A summary of the literature on global hearing impairment: Current status and priorities for action. Otology \& Neurotology 31.31-41.

Turner, Oliver; Kirsten Windfuhr; and Navneet Kapur. 2007. Suicide in deaf populations: A literature review. Annals of General Psychiatry 6.26.

**Tyler, Richard S.; Holly F. B. Teagle; Danielle M. R. Kelsay; Bruce J. Gantz; George G. Woodworth; and Aaron J. Parkinson. 2000. Speech perception by prelingually deaf children after six years of cochlear implant use: Effects of age at implantation. Annals of Otology, Rhinology \& Laryngology 109.82-84.

Tyler, Richard S.; Shelley A. Witt; Camille C. Dunn; Ann Perreau; Aaron J. Parkinson; and Blake S. Wilson. 2010. An attempt to improve bilateral cochlear implants by increasing the distance between electrodes and providing complementary information to the two ears. Journal of the American Academy of Audiology 21. $52-65$.

**Uziel, Alain S.; Martine Sillon; Adrienne Vieu; Françoise Artieres; JeanPierre Piron; Jean-Pierre Daures; and Michel Mondain. 2007. Ten year followup of a consecutive series of children with multichannel cochlear implants. Otology \& Neurotology 28.615-28.

van Hasselt, Piet, and Eric van Kregten. 2002. Treatment of chronic suppurative otitis media with ofloxacin in hydroxypropyl methylcellulose ear drops: A clinical/bacteriological study in a rural area of Malawi. International Journal of Pediatric Otorhinolaryngology 63.49-56.

Vermeire, Katrien; Jan P. Brokx; Floris L. Wuyts; Ellen Cochet; Anouk Hofkens; and Paul H. Van De Heyning. 2005. Quality-of-life benefit from cochlear implantation in the elderly. Otology \& Neurotology 26.188-95.

Walker, Grace. 2008. A conversation with Grace Walker: Personal experiences with a cochlear implant. Access: Multiple avenues for deaf people, ed. by Doreen DeLuca, Irene W. Leigh, Kristin A. Lindgren, and Donna Jo Napoli, 140-45. Washington, DC: Gallaudet University Press.

Waltzman, Susan B., and J. Thomas Roland, JR. 2005. Cochlear implantation in children younger than 12 months. Pediatrics 115. e487-e493.

***WILbUR, RonNIE. 2001. Sign language and successful bilingual development of deaf children. Journal of the Institute for Social Research 56.1039-79.

***Wilbur, RonNie. 2008. How to prevent educational failure. Signs \& voices: Deaf culture, identity, language and arts, ed. by Kristin A. Lindgren, Doreen DeLuca, and Donna Jo Napoli, 117-38. Washington, DC: Gallaudet University Press.

WiNEFIELD, RichARD. 1987. Never the twain shall meet: Bell, Gallaudet, and the communication debate. Washington, DC: Gallaudet University Press.

Wood, SANDRA. 2007. Degrees of resiliency in acquisition of language. Nanzan Linguistics (Special issue 3) 1.315-30.

WoOD, SANDRA. 2011. Acquisition of topicalization in very late learners of LIBRAS: Degrees of resilience in language. Deaf around the world: The impact of language, ed. by Gaurav Mathur and Donna Jo Napoli, 164-83. Oxford: Oxford University Press.

Woods, Bryan T., and Susan CAREY. 1979. Language deficits after apparent clinical recovery from childhood aphasia. Annals of Neurology 6.405-9.

Wrigley, Owen. 1997. The politics of deafness: Family handbook on adult hearing loss. Washington, DC: Gallaudet University Press.

**Yoshinaga-Itano, Christine. 2006. Early identification, communication modality, and the development of speech and spoken language skills: Patterns and considerations. In Spencer \& Marschark, 298-327. 
Yoshinaga-Itano, Christine; Diane K. Coulter; and Vickie Thomson. 2000. The Colorado hearing screening program: Effects on speech and language for children with hearing loss. Journal of Perinatology 20.s132-s142.

Yoshinaga-Itano, Christine; Allison L. Sedey; Diane K. Coulter; and Albert L. MeHL. 1998. Language of early- and later-identified children with hearing loss. Pediatrics $102.1161-71$.

Zeanah, Charles H.; Charles A. Nelson; Nathan A. Fox; Anna T. Smyke; Peter Marshall; Susan W. Parker; and Sebastian Koga. 2003. Designing research to study the effects of institutionalization on brain and behavioral development: The Bucharest Early Intervention Project. Development and Psychopathology 15.885-907.

Napoli

500 College Avenue

Department of Linguistics

Swarthmore College

Swarthmore, PA 19081

[donnajonapoli@gmail.com]

[thumphri@gmail.com]

[poorna.kushalnagar@gmail.com]

[gaurav.mathur@gallaudet.edu]

[cpadden@ucsd.edu]

[christian.rathmann@sign-lang.uni-hamburg.de]
[Received 30 July 2013;

accepted 22 January 2014] 